\title{
REVIVAL OF THE FADING INDIGENOUS SKILL THROUGH LIVELIHOOD CLUSTER: A NORTHEAST INDIA PERSPECTIVE
}

\author{
Mita Nath Bora \\ Assam Don Bosco University
}

\begin{abstract}
Traditional artisans of India are usually from the area of handloom and handicraft. With the availability of machine made products, most of these traditional artisans are facing sustainability issue. In Northeast India, the situation is more difficult due to the region's geographical isolation and most artisans are on the verge of giving up their skill and opting for alternative livelihood. To revive this sector, several efforts are being made since the last 2-3 decades and one such effort is through the cluster model. Pockets of 50/100 or more artisans practicing similar nature of traditional handloom or handicraft are grouped together to form a cluster and initiatives undertaken for their sustainability. To understand the impact, the study had the research questions - whether interventions made through clusters been able to provide better livelihood and better economic returns to artisans working within the cluster program and have artisans working in a cluster grown faster in their respective sectors than others working on similar products on their own. Primary analysis of survey of three clusters of northeast India, under a mixed methodology reveals that visibly the traditional skills have been revived through cluster efforts but tailor made approach needs to be made for progressive growth.
\end{abstract}

Keywords: traditional artisans, clusters, sustainability, economic growth, social growth

\section{Introduction}

The North-East India is geographically and culturally situated between two great cultural traditions of 'Indic' South Asia and 'Mongoloid' South East Asia. This geographical location had been an important factor in the development of a culture with a strong indigenous flavour (Gait, 1926). The principal old time industries in the region were weaving in country looms, pottery, blacksmithy, bell-metal and brass-metal works, goldsmithy, village carpentary, bamboo and cane works, spinning of endi (Eri), muga and mulberry silk, vegetable dyeing, wood carving, hand pounding of rice, manufacture of ivory products, etc. Many of these industries are now in decaying stage due to varied reasons like lack of capital and technical know-how, competition from machine made goods at cheaper rates, lack of marketing facilities, etc. However, some of the still prevalent indigenous skills of the northeastern states are in weaving, sericulture, gold washing \& jewellery, metal culture, pottery (Terracota), cane \& bamboo works, mostly in the handloom and handicraft sector.

The challenges faced by the indigenous artisans/weavers of these two sectors are multiple starting from them being traditional and un-organised with limited access to market and no structured supply chain management and therefore dependent on middlemen. These indigenous skill workers also use outdated technology and have inadequate access to credit. The indigenous artisans/weavers of the northeast region of India face additional challenges due to their ggeographical isolation and backwardness, inability to face new uncertainties and risk, inability to keep with market demand, very low investment capacity and hence low production.

Presently, these two sectors are the two most important non-farm activities in the northeastern region. Around 14.6 lakh units are engaged in handloom activities primarily in five States in northeast viz. Assam, Manipur, Nagaland, Tripura and Arunachal Pradesh (RBI, July 2006). Over $53 \%$ of the looms in the country and over $50 \%$ of the weavers belong to North Eastern States. However only $13.4 \%$ of the commercial looms of the country are in these States (MoT, 2014). In present times, there has been has been drop in handloom cloth 
production from 7585 to 6901 , i.e. $-0.86 \%$ during the period 2001-02 to 2011-12 and the number of handloom units has also dropped to $-4.38 \%$ (i.e. from 38.91 lakhs in 2001-02 to 23.77 in 2011-12) (MoT, 2014). In the last fifteen years, the number of clusters in these sectors is decreasing day by day but as they occupy an important place due to their traditional value and cultural importance they cannot be left to fade away as other countries did. There is a need to pay attention to safeguard them (Panneerselvan, n.d.).

Therefore, the organization of these industries into some kind of homogeneous clusters are increasingly recognized as an effective means of revival of the fading indigenous skill industry of the region and socioeconomic development of the artisans/weavers community. To reap the benefits of economies of scale and to transform these small disintegrated, unorganized sectors into viable entities the cluster approach is being used over the last few decades and several cluster initiatives has been started for the upliftment of these sectors.

In this research paper, an attempt has been made to study the impact of the cluster model towards reviving the indigenous skills of three clusters of north east states of India in the handloom and handicraft sector. The aim is to understand the socio- economic development aspects of the artisan/weavers (to be referred to as beneficiaries) involved in the 3 clusters, (Pyranga Eri Silk Cluster of Assam, Umden Eri Silk Cluster of Meghalaya, Hapania Jute Cluster of Tripura) as beneficiaries. Accordingly, the major research questions framed are :

\section{Interventions made through clusters have been able to provide better livelihood and better economic returns to beneficiaries working within the cluster program}

\section{Beneficiaries working in a cluster have grown faster in their respective sectors than others working on} similar products on their own

The paper is structured to include the theoretical definition of cluster and its relevance, followed by the methodology adopted to conduct the study along with a detail breakdown of the major research questions, followed by the findings, results and discussion on the findings.

This study is an original attempt to bring forth a first hand in depth analysis of selected natural clusters in existence in the north eastern states of India and the study also contributes to the literatures on the subject by covering pertinent aspects of the cluster. The final research shall help towards formulating better cluster policy for greater impact amongst the rural skill industry.

\section{Theoretical Background}

Clusters are defined as a group of small firms operating in a defined geographic location, producing similar products or services, cooperating and competing with one another, learning from each other and reaching distance market through developed networks (Jote, 2013). Clustering is used for development and upliftment of a region's economy and plays a major role in addressing several issues of an under-developed economy, of unemployment, poverty, etc. There has been intense interest in cluster concept and usage of cluster method for the economic development (Feser, 1998) and social development of a region (Marcolini, 2005).

Under normal parlance, the term cluster means a group of similar things or people positioned or occurring closely together. In context to the topic here, it means a group of firms, and related economic actors and institutions, that are located near one another and that draw productive advantage from their mutual proximity and connections. The first time the concept was used was in 1890 by Alfred Marshall which he referred to as agglomeration economies (Overman, 2010). And in 1990, Michael Eugene Porter broadened the scope of cluster concept by defining clusters as geographic concentrations of inter-connected companies and institutions in a particular field. The term cluster was first defined by Michael Eugene Porter in his book 'The Competitive Advantage of Nations' (Porter, 1990). Since then, the cluster concept has rapidly attracted attention from varied areas and many governments and industry bodies/organizations around the globe have turned to this concept as a means to stimulate urban and rural economic growth.

The process of identifying, defining, and describing a cluster is not standardized. UNIDO defines clusters as agglomerations of interconnected companies and associated institutions. Firms in a cluster produce similar or related goods or services and are supported by a range of dedicated institutions located in spatial proximity (UNIDO, 2010). The Department of Trade and Industry (UK) defines cluster 'as a geographic concentration of competing, collaborating and interdependent companies and institutions which are connected by a system of market \& non-market links' (Kuah, 2002, page 207). Harvard Business School defines clusters as geographic 
concentrations of interconnected companies, specialized suppliers, service providers, and associated institutions in a particular field that are present in a nation or region (HBS, 2015). Closer home, in the Indian context, cluster is defined as a sectoral and geographical concentration of enterprises and their various stakeholders \& service providers. It is an agglomeration of small and medium enterprises producing same/similar products/services or engaged in the same line of manufacturing activities or services, located within an identifiable and, as far as practicable, contiguous area. Under the Micro and Small Enterprise Cluster Development Programme (MSE CDP) a cluster is defined as a group of enterprises located within an identifiable and as far as practicable, contiguous area and producing same/similar products/services with the geographical bounds constituting even a mohalla, village, block, etc. (Sircar, 2008). The characteristics within the cluster being similar production methods, quality control and testing, technology and marketing strategies/practices as well as common challenges and opportunities.

The key aspect of cluster is that it helps in improving the quality of life and social well-being, by means of quality food, services, education, information, health, water, social protection schemes, etc. Life is improved for people who are living in a clean and protected environment and are socially included as noted by the National Strategy for Growth and Reduction of Poverty (NSGRP) (IMF, 2006), for example, many women working in micro clusters manage to contribute to their family income such that they keep above the poverty line - and are able to send their children to school and remain healthy otherwise. Similarly, the contribution of clusters towards employment generation, alleviation of poverty and inequalities and development of backward areas is recognized worldwide (Bahadur, 2012). Clusters of interlinked firms collaborating technologically and strategically are also known to contribute significantly to the economic growth and prosperity of the regions where they are located. Small and household firm clustering has assumed an increasingly important role in economic growth. When firms form clusters of economic activity, there are particular development strategies that flow in and throughout this area of economic activity. This helps to accumulate information and the flow of new and innovative ideas among firms for the achievement of what economists call increasing returns to scale.

For the purpose of this study, the MSE CDP definition of cluster has been taken into consideration, as the cluster selected for the study falls under this definition.

\section{Study Methodology}

In this research paper, the focus is to examine the impact of cluster approach towards revival of the indigenous skill of the artisans/weavers of the northeastern region of India and assess the impact it has made as regards to providing them better livelihood and better economic returns. i.e. create both social and economic impact alongwith their faster growth. The areas that were undertaken for the research are the Pyranga Eri Silk Cluster of Assam, the Umden Eri Silk Cluster of Meghalaya and the Hapania Jute Cluster of Tripura. The sample size covered was 600 of the 970 cluster beneficiaries from the above three clusters.

The methodology adopted was both qualitative and quantitative, i.e. mixed methodology survey encompassing tools like field study, focus group discussion, one-to-one interactions and also questionnaire survey. The research started with collecting secondary data and analyzing them followed by a pilot survey through a field visit. During the pilot survey interaction with few of the beneficiaries was held and this included focus group discussion with some of the earliest and oldest members of the cluster group. In-depth survey was undertaken to have a first hand understanding of the presence of the traditional skills in the defined area as practised by the locals, the nature of activities ongoing (in terms of scale and size), the visibility of the transformation, if any that had taken place, etc. To further collect data from the larger group of the beneficiaries, a detail questionnaire was developed which was purposefully kept open-ended to incorporate new and relevant information filtering in during the survey. Few more visits were made with the questionnaire during which one-to-one interaction and focus group discussion was again held along with visit to onsite workplace, at homes and work shed to see the changes being mentioned during the survey process.

The two broad research questions that was taken for the study were broken down to include relevant aspects for a detail analysis. To assess the social aspects of better livelihood, efforts were made to understand the awareness amongst the beneficiaries and whether this have helped them to form Self Help Groups (SHGs) along with whether they are themselves members of the same SHGs; whether there has been social upliftment, are their children getting proper education, do they have better housing facility, proper sanitation, proper drinking water facility, etc. Similarly, to access the economic impact, efforts were made to collect information of their bank account status, asset creation, possession of movable/immovable property, financial literacy, etc. For faster growth too, the relevant criteria taken into consideration were from both social and economic factors. Sample of some of the relevant questions are : 
Whether better credit linkages were provided to the cluster beneficiaries in terms of access to bank loans, micro credit facility, credit schemes, etc

Whether better market linkages were provided to the cluster beneficiaries, in terms of direct access to buyer, client, dealers, showroom, government departments, etc

Whether the cluster beneficiaries got proper exposure, as regard to participation in State/Regional/National exhibition, expo, fairs, buyer-seller meet, conclaves, etc

Whether the cluster beneficiaries have access to proper infrastructure in terms of working shed, machinery, tools, etc

Whether the cluster women beneficiaries were more eempowered as regard to managing their own account, visiting market, both for procuring raw materials and also for selling final products themselves, gained ability to voice out opinion in family matter and matters of their business, etc

These information are depicted as key questions in Table 1.1, Table 1.2 and Table 1.3 and their analysis accordingly shown.

\section{Brief Description and Analysis of each Cluster}

\section{Cluster 1- Umden Eri Silk Cluster, Meghalaya}

The Umden Eri Silk Cluster is located in the state of Meghalaya of north east region of India. Umden, under Nongpoh circle of Ri-Bhoi district of Meghalaya is a famous pocket of Eri silk weaving and traditional natural dyeing activity which were not harnessed to its fullest potential. The original skills of dyeing and weaving of the ancestral villagers, especially the women folks, were getting lost with time and the new weavers were unable to keep pace with the demands of design, variety and quality of products of the present market requirements.

To revive them, the first cluster intervention here took place in 2009, covering 278 artisans from 14 villages and the Umden Eri Silk Cluster was formed. Several challenges related to rigid mindset, aversion to new schemes, reluctance to change, use of outdated technology, reluctance to communicate and the biggest being language barrier existed in the initial stage of cluster formation. Therefore, as communicated by the cluster SPV (Special Purpose Vehicle) members, the first efforts made were to unify the weavers and natural dye experts as a group, create awareness, social capital mobilization, and then move slowly to the next stage of training in new and upgraded skills, design development, product diversification, along with technology upgradation and use of new tools, such as fly shuttle loom, jacquard loom etc., convergences with various department, such as State Handloom department, Sericulture department, National Institute of Design, etc. Once the weavers formed groups under SHGs, initiative were said to be taken to appoint a Network Development Agent (NDA) and form a Special Purpose Vehicle (SPV) so that a Common Facility Centre(CFC) can be established. Members of the SPV and cluster also were taken for exposure visits to related clusters outside the region.

During the period the study was undertaken, the cluster had 400+ registered beneficiaries, although the member list is 600, which means 200 are not yet to be registered. The cluster is spread over 14 Villages all under the Umden area. A good number of beneficiaries are third generation weavers and hence possess great traditional skill. The cluster have been able to achieve faster production which is otherwise a drawback in hand-woven products and also produce high grade quality products. Today, as communicated by the interviewees, all cluster members are proficient in making several types of Eri Shawl, Stole, Bags which are in great demand in the state of Meghalaya and also to some extent in the national and international market. Therefore, it seems that the cluster programme have been able to revive the dying art of Eri Silk of Umden and have been able to help the weavers of Umden continue with their traditional livelihood from weaving. Figure 1.1 gives a representative analysis of the feedback of the beneficiaries of Umden Eri Cluster as was gathered through one to one interaction and questionnaire survey. 


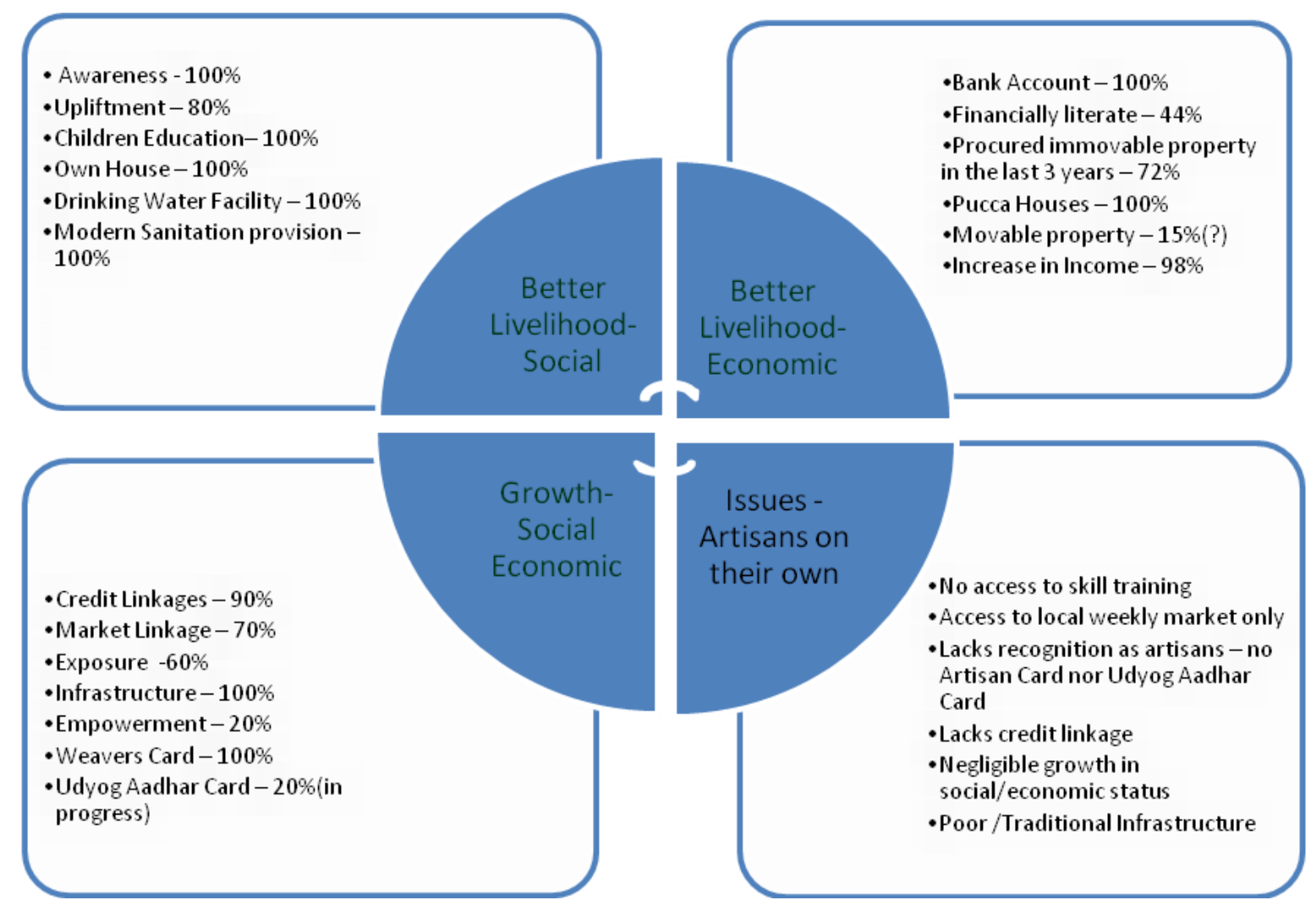

Figure 1.1 Representation Analysis of the status of Umden Eri Silk Cluster

However, what is also seen is that though the cluster have been able to form a SPV and also has a mini CFC, which has been facilitated through convergence with the State Government, the SPV thereafter hasn't been as active. Besides, the biggest challenge still remains in communication and language barrier due to which the cluster beneficiaries are not able to take advantage of markets outside Meghalaya. Also, due to the cluster being located in an interior remote hilly terrain, it is inaccessible and therefore hasn't yet got the market, promotion and clients it should get in comparison to the superior quality handloom products the weavers can produce.

\section{Cluster 2 - Pyranga Eri Silk Cluster, Assam}

The Pyranga Eri Silk Cluster is situated in the Boko area of south Kamrup district of Assam, comprising of Pub and Paschim Pyranga. As informed, this cluster was originally a BPL cluster which comprised of the Rabha and Muslim community. Though the tradition of Eri rearing, spinning and weaving was prevalent in this area since time immemorial, however, this was carried out in a very low scale. Most of the people had either abandoned or in the threshold of giving up the tradition due to ignorance about its potentialities and inability to commercialize it.

In 2009, covering these two villages the first cluster model was initiated with intervention carried towards overall socio-economic upliftment, unification as a group, skill upgradation, development of network, appointment of NDA, creation of convergence, provision of financial assistance, exposure visits, etc. The major challenges faced, like skepticism towards government initiative, poor quality and lack of design, ignorance of the vast potential of Eri products, dependence on middlemen, limited product line and pervasive poverty was slowly overcome with the passage of the cluster initiative. Multiple convergence with different departments and offices like Central Silk Board, RGVN, DRDA, etc were made which has helped the artisans to get benefit from the various government schemes available for entrepreneurial artisans, provided by the different departments; and also for further future collaboration. Earlier, the economic conditions of the weavers here were deplorable, which they mentioned have improved and their families are now able to construct concrete houses with sanitation and water facilities. Children are also able to attend proper school and live in a hygienic environment. 
During the course of the study the cluster had 200 beneficiaries who produce multiple products, with a willingness to learn and incorporate new market oriented designs and also attempted product diversification which are in great demand today. The cluster beneficiaries are prompt to take on and deliver orders and are able to sustain themselves. However, there still exists disharmony amongst the two villages and due to which the SPV is a weak body. The cluster also does not have a CFC which may help the beneficiaries to produce for the export market. Figure 1.2 below presents a representative analysis of the Pyranga Eri Silk Cluster as was gathered through one to one interaction and questionnaire survey.

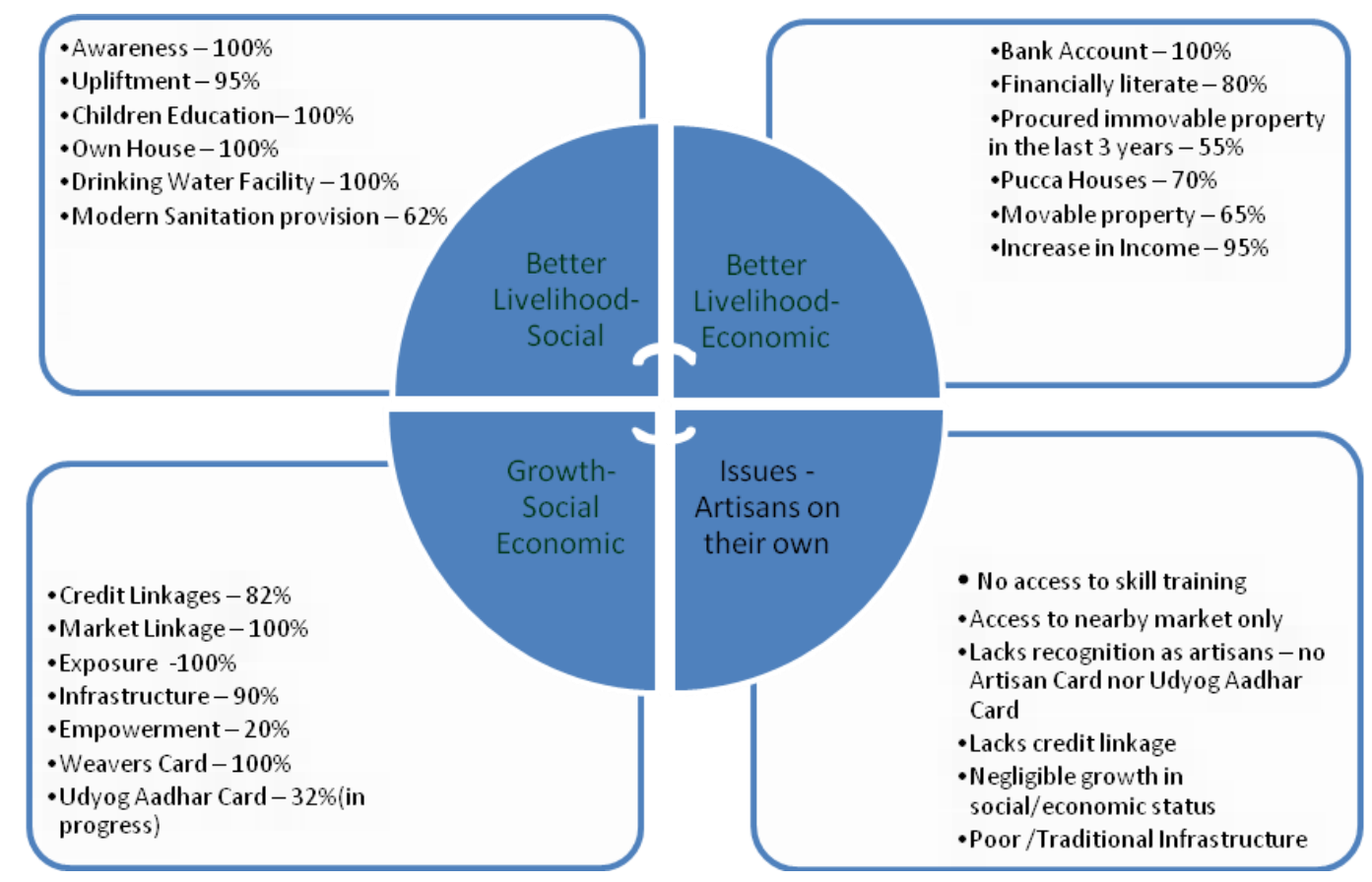

Figure 1.2 Representative Analysis of the status of Pyranga Eri Silk Cluster

\section{Cluster 3 - Hapania Jute Cluster, Tripura}

The Hapania Jute Cluster is situated approximately at a distance of $6 \mathrm{kms}$ from Agartala, in West Tripura district. It provides sustainable livelihood to 500 families who produce various jute based handicraft product as their primary source of income. The cluster which originated from the presence of a jute mill and the Tripura Jute Mill Play Centre in the region promoted various vocational training amongst the family members of the jute mill. From 2002, it started producing various jute based products and this became an important source of earning for many families of the cluster.

The formal cluster model started in Hapania in 2012, with an initiative to first overcome the problems of low return, laborious production process, quality concerns, etc. The cluster was challenged by the presence of strong middlemen, inadequate price and low returns, lack of standardization, lack of proper design, poor marketing network, traditional technology, etc. which the cluster model sought to address one each at a time, through its intervention.

As mentioned during the study, one major change brought in the cluster was the initiative to create new product development and redesigning of existing product under the Design Clinic Scheme. Design intervention through different training programmes were conducted and the use of local tribal motifs and natural colours, environmentally oriented visual motifs were encouraged and introduced which created a strong visual and regional identity for the cluster. Technique of using a combination of different materials were taught which helped to strengthen the jute with which a range of new products such as baskets, lamp shades, tabletop, accessories etc. were made possible. Today, the cluster beneficiaries produce a variety of mats, such as foot mats, sitting mats, table runners, etc. Also new products, like hand bags, shopping bags and baskets, file cover, 
file bag are now produced in large quantities. Jute cloths without plastic lamination are now being used to come up with a range of eco-friendly carry bags which has great demand.

The cluster during the study had 370 beneficiaries with a strong SPV and continuous marketing effort by the SPV, though the beneficiaries still lack self-motivation. This cluster also lacks proper infrastructure in terms of a CFC to facilitate the beneficiaries to take on large orders and carry on volume production. Figure 1.3 below shows the representative analysis of the feedback received from the beneficiaries of the Hapania Jute Cluster as was gathered through one to one interaction and questionnaire survey.
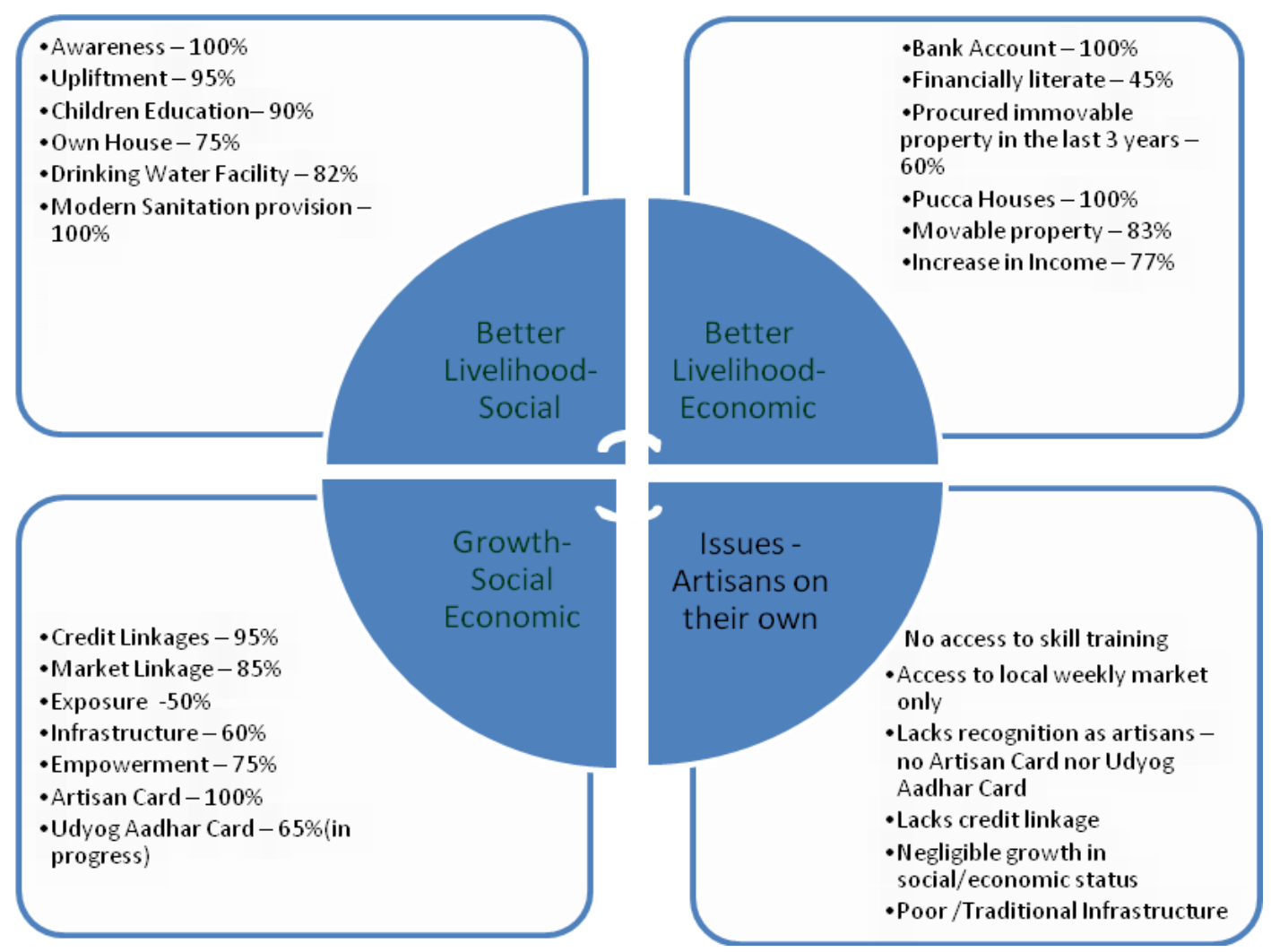

Figure 1.3 Representative Analysis of the status of the Hapania Jute Cluster

\section{Analysis of the Findings}

Following are the key questions that had been taken during the course of the field study with their results therein.

Table 1.1 Key Questions to assess better livelihood-Social

\begin{tabular}{ll}
\hline $\begin{array}{l}\text { Key Questions } \\
\text { Member of SHG }\end{array}$ & $\begin{array}{l}\text { Results } \\
\text { Awareness of } \\
\text { schemes/facilities }\end{array}$ \\
Children Education & Many now aware of schemes/facilities \\
Housing facility & $\begin{array}{l}\text { Almost every beneficiary children receive basic } \\
\text { education }\end{array}$ \\
Sanitation provision & Exists in all 3 clusters \\
Drinking Water facility & Exists in all 3 clusters \\
Recognition as an Artisan & Exists in all 3 clusters \\
\hline
\end{tabular}


Table 1.2. Key Questions to assess better livelihood-Economic

\begin{tabular}{ll}
$\begin{array}{l}\text { Key Questions } \\
\text { Own Bank Account }\end{array}$ & $\begin{array}{l}\text { Results } \\
\text { As mandatory, all beneficiary has opened bank account } \\
\text { Financial Literacy }\end{array}$ \\
$\begin{array}{l}\text { To certain extent } \\
\text { Possessing Assets } \\
\text { Mousehold assets such as TV, Refrigerator. Working Assets such as } \\
\text { looms, machines } \\
\text { property }\end{array}$ & $\begin{array}{l}\text { Own land, Agricultural land, Work shed, Car } \\
\text { Pucca Houses }\end{array}$ \\
$\begin{array}{l}\text { Increase in Income } \\
\text { More than half of the cluster families possess concrete houses }\end{array}$ \\
$\begin{array}{l}\text { Evists for new income earners, previous domestic weavers after being } \\
\text { Possess } \\
\text { Looms/Machines/Tools beneficiaries } \\
\text { Capacity to buy raw } \\
\text { material }\end{array}$ & $\begin{array}{l}\text { Has access to banks and financial institutions } \\
\text { Exists amongst the cluster families }\end{array}$ \\
\hline
\end{tabular}

Table 1.3 Key Questions to assess faster growth

$\begin{array}{ll}\text { Key Questions } & \text { Results } \\ \text { New designs } & \text { Learning and acceptance of new designs } \\ \text { Product diversification } & \text { Beneficiaries adopted production of diversified products } \\ \text { New market penetration } & \text { Happened in some cases } \\ \text { Adoption of new technology } & \begin{array}{l}\text { This has happened and greatly benefited the } \\ \text { artisans/weavers }\end{array} \\ \text { Increase in Order \& Client/Customer } & \text { This have increased over the last few years } \\ \text { Increase in Production } & \text { Exists } \\ \text { Increase in Sales } & \text { Exists } \\ \text { Increase in Profit } & \text { Exists } \\ \text { Increase in Income } & \text { Exists } \\ \text { Provision of Exposure } & \text { Opportunities given } \\ \text { Participation in Exhibitions/Expos/Fairs } & \text { Beneficiaries availed opportunity to participate } \\ \text { Confidence to directly deal with } & \text { Gradually happened over time } \\ \text { customers } & \text { Beneficiaries moved beyond producing only for domestic } \\ \text { Creating products beyond household } & \text { requirement } \\ \text { requirement } & \text { Many cluster beneficiaries today contribute to family } \\ \text { Financial Independence } & \text { expenditure }\end{array}$

It is seen from Table 1.1 that on an overall due to the cluster intervention, almost all beneficiaries are now aware of the cluster facilities, various schemes and policies available to artist and weavers and their need to form SHGs and be member of the same to get the benefits. Almost all cluster beneficiaries are now able to send their children to school for primary education, many pursuing college education and graduation. Few clusters beneficiaries also have children undergoing professional courses. Almost all cluster beneficiary families have proper housing facility with clean drinking water facility and also good sanitary provision.

The most important part of the cluster intervention model is that cluster beneficiaries are today recognised as artisans and weavers and posses weavers Credit Card and Artisans Card, provided by their State Handicraft department (DC, Handicraft) and State Handloom department respectively. 
The findings in Table 1.2 show that as necessitated by the cluster model, all cluster beneficiaries today have their own bank account and have knowledge of operating their bank account. They are aware of the credit schemes for artisans/weavers and also for their other livelihood activities such as agricultural loan, etc. Though, not all are confident to take advantage of these facilities till now. Almost all cluster families possess good own land for building houses and also good agricultural land for their primary occupation, i,e, agriculture. Many have newly built concrete houses in place of the previous mud hut/ even wooden houses in hilly terrain. As regard, increase in income, the findings show that not only have the previous weavers/artisans who used to produce only for own consumption and use by themselves and family members, have now over the last 5-6 years started producing for sale in the local markets, started taking orders from their handloom department, society and also from individual clients. New weavers/artisans have also joined the skill in few pockets and have become new income earners. The earlier commercial producers, countable few, who were working on small scale have started to grow in size and scale. And many amongst them have availed of the credit schemes available for weavers from the Weavers Credit Card and the artisans also started to take the facilities provided by their Artisan Card.

As a direct benefit of being a cluster member was that all cluster beneficiaries today possess upgraded weaving looms/machines/work shed, etc. Due to the awareness created as a part of the cluster model, almost all cluster beneficiaries have knowledge of the pricing of raw material in the nearby markets, their availability, various grades and quality, and the sources/market of wholesale raw material providers.

Table 1.3 depicts that those artisans/weavers who became members of the cluster model could benefit from the opportunities, facilities being provided through the cluster intervention. Beneficiaries over time got the opportunity to learn and adopt new skill, designs and motif in their traditional products, they incorporated product diversification and scaled up the variety of goods produced.

As also mentioned in Table 1.2 that adoption of new technology, in terms of upgraded tools, looms, machineries has greatly benefitted the cluster beneficiaries to increase and improve the quantity and quality of their produce. Beneficiaries learnt to handle and use modern machines, like steel looms and wooden proper looms in place of floor looms, automatic sewing machines with various design and embroidery option in place of ordinary sewing machines, etc. These have led to their increase in production and increase in ability to take orders, thereby increasing sale, leading to more income and profit. Beneficiaries said that they have not only been financially independent but are also able to contribute to monthly family expenditure. Besides, with provision for exposure many artisans/weavers have been able to incorporate their learning from exposures outside the region and have said to eagerly participate in regional and national exhibitions and fairs.

\section{Discussion on the Overall Findings}

The overall findings of the study of the 3 clusters show that through cluster model, efforts initiated brought the maximum growth has been in the social aspects (90\%) followed by the provision of both credit and market linkages $(89 \%$ and $85 \%)$ respectively.

Table 2.1 shows an overall analysis of the 3 cluster and the growth in general the cluster beneficiaries has had over the years since cluster interventions.

\begin{tabular}{|l|l|l|l|l|}
\hline \multicolumn{1}{|l|}{ Aspects } & Cluster 1 & Cluster 2 & Cluster 3 & $\begin{array}{l}\text { Overall } \\
\text { (Primary Analysis) }\end{array}$ \\
\hline Better Livelihood- Social & $96 \%$ & $92 \%$ & $90 \%$ & $90 \%$ \& above \\
\hline Better Livelihood -Economic & $61 \%$ & $77 \%$ & $60 \%$ & $60 \%$ \& above \\
\hline Growth - Social Economic & $90 \%$ & $82 \%$ & $95 \%$ & $89 \%$ \\
\hline Credit Linkages & $70 \%$ & $100 \%$ & $85 \%$ & $85 \%$ \\
\hline Market Linkages & $60 \%$ & $100 \%$ & $50 \%$ & $70 \%$ \\
\hline Exposure & $100 \%$ & $90 \%$ & $60 \%$ & $83 \%$ \\
\hline Infrastructure & & & \\
\hline
\end{tabular}


The findings in the above table answers the following key questions as stated the Study Methodology.

Whether better credit linkages were provided to the cluster beneficiaries in terms of access to bank loans, micro credit facility, credit schemes, etc

Whether better market linkages were provided to the cluster beneficiaries, in terms of direct access to buyer, client, dealers, showroom, government departments, etc

Whether the cluster beneficiaries got proper exposure, as regard to participation in State/Regional/National exhibition, expo, fairs, buyer-seller meet, conclaves, etc

Whether the cluster beneficiaries have access to proper infrastructure in terms of working shed, machinery, tools, etc

Whether the cluster women beneficiaries were more empowered as regard to managing their own account, visiting market, both for procuring raw materials and also for selling final products themselves, gained ability to voice out opinion in family matter and matters of their business, etc

What we can see is that a whole the artisans/weavers who are members of a cluster have been benefited and the cluster model have been able to bring about drastic change in reviving the traditional skill of the weavers/artisans and enabled them to have a sustainable livelihood out of the skill. So the growth has taken place more on the skill enhancement and social upliftment (shown in Figure 2.1). However, much is to be achieved in terms of economic growth and at an individual level, not all has managed to grow exceptionally to make their skill as a primary earning source. They still have to depend on other livelihood options.

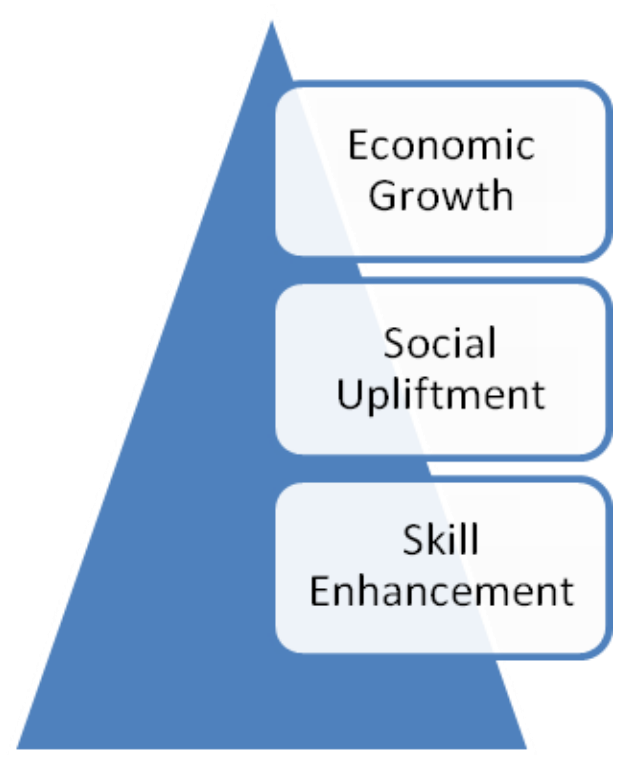

\section{Concluding Remarks}

Through the study carried it is observed that during the implementation of cluster model in the northeastern states of India, especially amongst the area where the study was undertaken, when sharing of resources, scale, technology, knowledge, expertise and information are made, it becomes advantageous to the groups, i.e. cluster beneficiaries as a whole. Interventions through the cluster model did help revive the old traditional natural clusters. The study leads to a definite conclusion that cluster program is most essential and can be extremely 
effective for bringing the traditional skill to the forefront, however, other factors have to aligned in terms of having the various stakeholders involved in the process of change and development. The success of the cluster development program depends on a large number of facilitating agencies and functionaries, like the concerned Central Ministry/ Department, the concerned State Government and its line department, the regional offices and developmental institutions of the MSME, the scientific establishments of the MSME, specialized technical and research institutions.

It can be concluded that though several impacts have been made through cluster model soft interventions and convergences, these clusters have not been able to graduate to Common Facility Centres to scale up production to compete with the market demand and standard requirement and also to challenge the flow of machine made products. To reach to that level, the cluster model needs to be re-looked from the region's perspective. In many of the states of the north eastern region, considering the difficult geographical location (with $70 \%$ of hilly terrain) and density of population, the national cluster model, which is a general model for all across India, may not bear fruitful results for the indigenous artisans/weavers cluster here; and hence, there is a necessity to adopt a flexible and tailor made approach in cluster policy and develop a separate cluster model for the northeastern states of India.

This study not only discusses and puts forth the actual status of the cluster impact in the 3 states of the north east region of India, it also adds to the documentation on the subject. Due to lack of any research in this area, there has been shortage of literature on the subject and this difficulty was faced during this study too. However, this study contributes and add to the literatures of the ground status of cluster implementation and its impact in the north eastern states of India.

The study also contributes to the literature of the existence and revival of various handloom and handicraft clusters in the north east states of India.

\section{References}

Bahadur, S., 2012. Report on Rural Cluster Development. A Case Study, New Delhi: Planning Commission, GoI.

Feser, E. J., 1998. Old and new theories of industry clusters. Clusters and Regional Specialisation. London: Pion.

Gait, E., 1926. A History of Assam. Calcutta: White Lotus.

HBS,H.B.S.,2015. What Are Clusters?. [Online] Available at: http://www.isc.hbs.edu/competitiveness economic-development/frameworks-and-key-concepts/pages/clusters.aspx

[Accessed 4 March 2015].

Jote, N. B. B. K. D. A. A., 2013. AHP-based micro and small enterprises' cluster identification. International Conference of Soft Computing and Pattern Recognition (SoCPaR), 2013.

Kuah, A., 2002. Cluster Theory and the Small Business. Journal of Research in Marketing and Entrepreneurship, p. 207.

Marcolini, P., 2005. The Role of Clusters in Local Economic and Social Development: the Italian Experience Some issues from the Marche Region. [Online] Available at: http://www.oecd.org/cfe/leed/34851563.pdf [Accessed 10 June 2015].

MoT, 2014. Strategic Plan(2012-2017), New Delhi: Ministry of Textiles.

Overman, H. P. D., 2010. Labor Pooling as a Source of Agglomeration: An Empirical. National Bureau of Economic Research, pp. 133-150.

Panneerselvan, R. R. L., n.d. Plotting and Studying the Problems Faced by the Handloom Industry Using Ishikawa Diagram. [Online] . Available at: http://www.fibre2fashion.com/industry-article/5867/plotting-andstudying-the-problems-faced

[Accessed 10 July 2017].

Porter, M., 1998. On Competititon. s.l.:Harvard Business Press.

RBI, July 2006. Report of the Committee on Financial Sector Plan for North Eastern Region, Mumbai: Reserve Bank of India. 
Mita Nath Bora / Revival Of The Fading Indigenous Skill Through Livelihood......

Sircar, J., 2008. Definition of Cluster. New Delhi: s.n.

UNIDO, 2010. Independent Thematic Evaluation. UNIDO Cluster and Networking Development Initiatives, Vienna: United Nations Industrial Development Organization. 